The Pictish Race and Kingdom

Author(s): James Ferguson

Source: The Celtic Review, Vol. 7, No. 25 (Feb., 1911), pp. 18-36

Published by:

Stable URL: http://www.jstor.org/stable/30070376

Accessed: 13-03-2016 17:12 UTC

Your use of the JSTOR archive indicates your acceptance of the Terms \& Conditions of Use, available at http://www.jstor.org/page/ info/about/policies/terms.jsp

JSTOR is a not-for-profit service that helps scholars, researchers, and students discover, use, and build upon a wide range of content in a trusted digital archive. We use information technology and tools to increase productivity and facilitate new forms of scholarship. For more information about JSTOR, please contact support@jstor.org. 


\section{THE PICTISH RACE AND KINGDOM}

\section{JAMES Ferguson}

I

Among the obscure periods in history, there is none more alluring or more tantalising in the absence of authentic records than the two hundred years which followed the withdrawal of the Roman legions from the northern walls, and submerged an advanced state of civilisation in Britain under the waves of barbarian invasions. 'The frontier,' wherever it may be, always exercises a powerful charm on the imagination, but nowhere is the spell more felt than where the rude Roman eagle, carved on the native rock, faces the unconquered shores of Fife, and on the long line of the fortified limes from the narrowing Firth to below the Fords of Clyde the legionary gazed across the central depression of Scotland to the Caledonian forest and the untamed Highland hills. We know not how the northmost wall was forced or turned, though tradition associates the feat with the ancestor of the house of Graham, or how the more formidable barrier, from Tyne to Solway, was breached or scaled, though the locality of the successful attack seems preserved in the name of Thirlwall. All that is certain is that the assailants of the province were the Picts and Scots, and that the Romanised Britons were unable to prevent their raids being carried far into the heart of England. The Scots survived to give a royal race and name to the whole country north of the Cheviots, but of the Picts, the most numerous and powerful, the name has disappeared, and for long history accepted and recorded their conquest and extermination, while the subject of their race and language has vied with the Ossianic controversy in providing one of the most fiercely contested battlefields of historians and antiquaries. Of the four kingdoms which existed within the area of modern Scotland between the years 500 and 850 A.D., that of the Picts was 
most extensive in territory, and for long occupied a position of supremacy. The disappearance of the name and the assumed destruction of the race is probably due to two causes. The one was, of course, the unvaried testimony of the mediæval chroniclers and historians to an exterminating conquest by Kenneth Macalpine, and the other is the fact that the Celtic race in these islands was preceded by a socalled Iberian race of totally different language and characteristics. The Iberian race was long-skulled, short of stature, dark-complexioned, with curly black hair; and a people of this character was found by the Romans in the Silures of South Wales. The existence of such a race in Scotland is proved by sepulchral remains, and a few traces of its language are discoverable in the names of some great natural features of the country, such as rivers. The memory of these older inhabitants is probably responsible for the local traditions which the Scottish peasantry has associated with the name of the Picts, which tell of the existence of a small dark race, give to the small subterranean dwellings that are found in many parts of Scotland the name of ' Picts' Houses,' and record how, when the last of the Picts were driven to the Mull of Galloway, the sole survivor was offered his life on condition of disclosing the secret of the brewing of their famous heather ale, but preferred to leap from the rocks into the sea. To the Picts, as known to be the predecessors of the Scots, and believed to have been exterminated, tradition would easily transfer incidents and characteristics of an earlier race. With more reason it gave to the Roman wall between Forth and Clyde the name of 'Picts Dyke'; to the mysterious rampart that runs from Loch Ryan to the Nith between Galloway and Carrick those of 'Picts Dyke,' 'Picts Wall,' and 'Deil's Dyke,' and to the other ancient artificial boundary, the 'Catrail,' which runs from the Gala to the Liddell, that of the 'Picts Ditch' or 'Picts Work.' The first of these was a defence against the Picts, the second was either a defence of their territory of Galloway against attack from the north, or of the British 
territory to the north against attack by the Galloway Picts. From the fact that the fosse lies to the north of the rampart which is invariably eight feet broad at the base, it would seem that this work 'carried in a right line over marsh and moor, forest, mountain and flood for full fifty miles,' 'between Caer Ryan and Caer Rywg,' was, as Skene suggests, a protection to the valleys on the north side of the Solway Firth, erected when the later Constantine counselled the provincial Britons to abandon the territory between the walls, before finally withdrawing the legions. The third, though probably a boundary between the Britons of Strathclyde and the Angles of Bernicia, may date from a period prior to the coming of the Angles, when the eastern districts between the northern wall and the Cheviots had been more or less occupied by Picts from beyond the Forth.

When authentic history first sheds its light on Britain, after the Roman exodus, Scotland is found occupied by four races, of which the Picts possessed practically the whole country north of the Forth, except Argyllshire, recently colonised by the Scots, while Galloway, from the Nith to the Irish Sea, was also inhabited by Picts. Ayr, Renfrew, Lanark, Dumbarton, and possibly part of Stirling formed the British kingdom of Strathclyde, and the south-eastern counties had been conquered, occupied, and to a large extent re-named by the Teutonic Angles of Northumbria. But in the Pictish population in central Scotland, between the Forth and Tay, there seems to have been a substantial British element, while the name of the Pentland Hills points to a considerable settlement of Picts in the regions south of the wall. Such being the distribution in which they are found, the question, 'Who and what were the Picts?' has received many suggested solutions. The facts that they occupied the whole of the eastern Lowlands, and that the prevalent tongue in that region for centuries has been the Teutonic 'braid Scots,' while Tacitus had commented on the resemblance of the natives to the Germans, led Sir John Sibbald and Pinkerton to maintain that they were of Gothic 
or Teutonic blood and spoke ' braid Scots' while yet pagans. The facts that Cæsar wrote of the Britons as painted, and as having wives in common, that the Picts owed their name to the practice of painting or tattooing the body and are said by later classic writers to have had wives in common, and some rapid conclusions and delusive speculations in phonetic etymology, led Harry Maule of Melgum and Chalmers to maintain that they were British Celts, akin to those of Strathclyde and Wales. Innes, in his Critical Essay of 1729, which is the pioneer work in real Scottish historical investigation, E. W. Robertson, in Scotland under her Early Kings, Colonel James Robertson, and Forbes Skene, basing their conclusions on a more detailed study of topography, on a critical examination of the earliest authentic annals, Scottish, Irish, and Welsh, and on a reasoned consideration of ascertained historical facts, are satisfied that the Picts were Gaelic Celts, akin in race and language to the Scots of Ireland and Argyll. Professor Rhys of Oxford considers them as what he calls an ' Ivernian race,' pre-Celtic both in Ireland and Scotland. There is this foundation for at least two of these opinions, that in certain regions the Picts were brought into close connection and intermarried with the Britons, occupying in central Scotland territory that had been previously held by Britons, and south of the Forth having possibly been superseded by Britons during the Roman occupation, and after the Roman evacuation seizing tracts of territory between the walls. One of the old legends says that the Picts 'conquered Scotland from Cath to Forcu' (Caithness to Forth), 'but without destroying the people,' and the so-called 'black Celt' in Scotland, Wales, and Ireland is probably not a Celt at all, or only to a limited extent, but the survival of an inferior subject population of lower type and development. It would seem that the view of Professor Rhys is curiously like that of the Scottish peasant. The sound conclusion appears to be that the Picts were truly the first Gaelic immigrants into or invaders of Scotland, that they were closely akin to the Scots who 
followed them at least in Scotland, and pressed on them both in Ireland and Scotland, and that the Gaelic race of the present day represents the amalgamation of Pict and Scot, while the Pictish blood has blended with the Teutonic to form the mass of the population in the north-eastern lowlands. It may be that the Picts were nearer akin to the Teutonic races than the Scots, and they seem to have coalesced more readily with them in Galloway and northeastern Scotland; but that they were in the main a Celtic and Gaelic race seems in the light of fuller investigation incontestibly established. The grounds of this conclusion are to be gathered from the references to the natives of northern Britain in the classical authors, from the early authentic Irish, Welsh, and Saxon notices, from inferences afforded by the ancient legends of their origin, from the evidence of topography, and from such indications as have otherwise been left of their language.

The wars with the Brigantes, the great British nation of northern England, extended the Roman power to the Cheviots, and made them aware of the existence of other tribes to the north, whom they called the Caledonii Britanni. In A.D. 79 Agricola embarked on his northern campaigns and reduced the districts to the north of the Solway. In the following year he advanced across the watershed, and, finding what Tacitus calls 'new nations,' occupied the country from Clydesdale to the Tay. Having fortified the isthmus between the Forth and Clyde with detached forts in the next year, he in 82 seems to have crossed the Clyde estuary, and viewed the Irish coast from Kintyre. In 83 and 84 he crossed the Forth, while his fleet passed to the Tay, and towards the end of the campaign the Caledonians made a determined and nearly successful attack on the 9th Legion. In 86 he penetrated Strathmore and the famous battle of the Mons Grampius took place, in which he met a confederacy of the northern tribes, and though Roman discipline was successful, and the detached forts previously established between the Forth and Tay may have been garrisoned, 
the victor returned to the province south of the Forth. While Tacitus ventures the opinion that the red hair and large limbs of the Caledonians might infer a German origin, as the swarthy features and crisp hair of the Silures suggested Iberian descent, and the other Britons resembled the Gauls, he says nothing of any difference in language, such as exists between the Celtic and Teutonic tongues. In 120 the Emperor Hadrian constructed the great wall from the Tyne to the Solway, and about that time the geographer Ptolemy compiled from the accounts of Roman soldiers and sailors his description of Britain, which, when allowance is made for the mistake by which the Mull of Galloway is given the position of Cape Wrath, is wonderfully accurate. The country to the north of the southern wall was then occupied by some sixteen or fourteen tribes. The district to the Forth on the east was held by the Ottadini and Gadeni, and Dumfriesshire by the Selgovæ, these tribes being probably a portion of the Brigantes. Modern Galloway from the Nith westward by the Novantæ or Men of the Novius (the Nith). The counties of Ayr, Renfrew, Lanark, Dumbarton, Stirling, and the districts of Menteith, Strathearn, and western region of Fife and Kinross to Loch Leven and the Tay by the Damnonii, who appear to have been akin to the tribe of the same name in Cornwall. East Fife, Forfar, and Mearns by the Vernicomes; the north-eastern lowlands from the Mounth to the Moray Firth by the Taexali ; the central district, from the Moray Firth to the Tay, by the Vacomagi ; that from Loch Long to the Beauly Firth by the Caledonii; easter Ross by the Canteæ or Decantæ; Sutherland by the Lugi and Mertæ; Kintyre and Lorn by the Epidii ; the west coast from Loch Linnhe to Loch Carron by the Creones, to the north of whom were the Cærini ; while the northern coast was held by the Cornavii. In 139 the country between the walls was again subdued, and the northern wall of turf constructed by Lollius Urbicus. In 201 the northern tribes appear as the Caledonii and Meatæ, the Meatæ being the natives of the regions next the 
wall, and the Caledonii those of the mountainous regions beyond, the names probably meaning men of the plain, and men of the forest. In 209 the Emperor Severus 'advanced into Caledonia,' penetrated to Burghead, reconstructed the northern wall, and obtained the cession of the central district, probably that originally occupied by Agricola, but within the year the Meatæ had again revolted. The name of Pict first appears in the year 296, when Eumenius, the panegyrist of Constantine Chlorus, uses the expression, 'Caledonum aliorumque Pictorum,' and in the phrase, 'prolixo crine rutilantia,' alludes to the physical characteristics which had attracted the attention of Tacitus. In 360 began the inroads of the Picts and Scots, the Picts clearly coming from the north, and the Scots assailing the western coast from Ireland. In 369 the elder Theodosius reconquered the region between the walls, and the Picts are again treated as consisting of two nations, the Dicalidones and the Vecturiones, these being evidently the Caledonians and Meatæ. Of Theodosius the poet Claudian says:-

' Ille, ... nec falso nomine Pictos

Edomuit, . . . Incaluit Pictorum sanguine Thule.'

When, after the withdrawal of troops by Maximus, a legion was again sent by Stilicho the same poet, in recording its successes, says :-

\footnotetext{
'Venit et extremis legio pretenta Britannis Quæ Scoto dat fræna truci, ferroque notatas Perlegit exsangues Picto moriente figuras.'
}

The final withdrawal of the legions in 407 was followed by the overrunning of the country to the southern wall, and by the invasion of the barbarians in 409 ; while in 410 the letter of Honorius to the British magistrates, instructing them to provide for their own defence, signified the termination of the Roman sway in Britain.

In all the classic references there is nothing to suggest that the northern tribes were other than the same race throughout the four hundred years of Roman intercourse, 
and the classic authors clearly indicate Caledonia north of the Forth as the country of the Picts. The physical appearance, the weapons and modes of warfare described, and the social customs indicated, are all consistent with and support this view. Cæsar had recorded that the Britons of the interior were a pastoral people, that their towns were fortifications in the woods, that they used chariots in warfare, that they painted the body, and that they had their wives in common. Tacitus describes the chariots, the long swords, and the shields of the Caledonians, though it is remarkable that he says nothing of the painting or of the community of wives. Ptolemy mentions the names of a few towns, these being more numerous in the country of the Damnonii, and becoming fewer as the northern tribes are reached. In the time of Severus the Caledonians are described by Dio as living by pasturage and the chase, as using chariots in battle, as armed with sword, shield, and dagger - the arms of the clansmen in later years-with which they had also a short spear with a loose brass ring at the shaft, as practising the painting or tattooing of the body, and as having a community of wives between ten or a dozen persons. The persistence of the name 'Picti' or painted, in Latin, Welsh, and Irish, and the lines of Claudian prove that the practice of painting the body continued down at least to the end of the Roman occupation. There can be no reasonable doubt that the Picts of the country north of the Forth were just the Caledonii of Tacitus, under a descriptive name, and the same is true of the natives of Galloway, who were originally known as the Novantæ, from the Roman name of the Nith, who were written of within a century after the Roman occupation by the Welsh bards as 'Novant' and 'Peithwyr,' who are described by Bede as 'Pictorum qui Niduarii vocantur,' or Picts of the Nith, and who are found under the name of Galloway Picts in the Scottish army at the battle of the Standard in the reign of David I.

At an earlier period the whole of Ulster was inhabited by a Pictish people, and under the name of 'Cruithnigh,' the 
Irish equivalent of the word Picts, a people of this race recognised as such continued to occupy a district consisting of the county of Down and the south half of Antrim, known as Uladh or Dalaradia, the Scots being in possession of the Irish Dalriada to the north. The Cruithnigh of Ireland were the race which had ruled over Ulster from Emania, to which the knights of the Red Branch belonged, and with which are associated some of the most famous Irish legends. Of them were the sons of Uisneach, and it would seem that Fingal, Ossian, and Diarmaid were the common heroes alike of the Caledonian and of the Hibernian Picts.

The knowledge possessed by the Britons of their Pictish neighbours is recorded by Gildas and Nennius. Gildas, who wrote about 556 A.D., calls the Picts a transmarine nation who came from the north-east, ab aquilone, and says that on the withdrawal of the legions they occupied the districts up to the southern wall as natives, and that when finally repelled by an effort of the provincial Britons they settled down for the first time in the northern part of the island, where they were when he wrote his history. Nennius, who wrote in 858, says the Picts came and occupied the Orkney islands, whence they laid waste many regions, and seized those on the left (or north?) side of Britain, where they remained to his day holding a third part of Britain. 'The tradition of the Cymri,' writes E. W. Robertson, " unites the Gwyddil Ffichti or Gaelic Picts with the Coranied and the Saxons as "the three intrusive tribes" who acquired settlements in Britain by force of arms, bringing the Picts "over the sea of Loch Flyn," the northern ocean, and placing them "in the Alban along the shores of the Mawr Tawch," in other words, along the coast of Scotland beyond the Forth.' The Saxon Bede says, 'At first this island had no other inhabitants than the Britons, but when they, beginning at the south, had made themselves masters of the greatest part of the island, it happened that the nation of the Picts, from Scythia as is reported, putting to sea in a few long ships, were driven by the winds beyond the 
shores of Britain, and arrived on the northern shores of Ireland, where, finding the nation of the Scots, they desired a settlement among them; and this being refused by the Scots they sailed over to Britain, and began to inhabit the northern parts of the island.' He adds that having no wives they applied to the Scots who gave them on condition that when the succession came into doubt, they should choose their king from the female royal race rather than from the male, a custom which, he says, it is well known, is observed among the Picts to this day. He also indicates that the twofold division of the Picts referred to by the Roman writers continued, for he says that the provinces of the northern Picts were separated by high and lofty mountains from the southern regions of that people, the reference being obviously to the Grampians and the Mounth. That communication existed between the southern Picts of central Scotland and the Picts of Galloway is also indicated by his statement that the northern Picts were only converted to Christianity by St. Columba in 565, while the southern Picts had long before embraced Christianity through the preaching of St. Ninian, who founded the church of Whithern in Galloway shortly before the Roman evacuation.

There is a mass of legendary history, British, Irish, and Pictish, as to the origin of the races in these islands, which mainly seems to consist of putting into a genealogical form the distribution and believed relations of the various peoples. The Irish legends deal with the Scots and Picts, and it is sufficient to say that they point to a close connection between the two races. Thus in the distribution of Ireland among the sons of Miledh, it is to the descendants of Ir that Ulster, the region for many generations ruled and occupied by the Picts, is assigned, and among the names of Pictish monarchs who ruled both ' in Erin and Alban' are several whose names appear in the Irish Annals as kings of Ireland of the race of Ir. The tradition as to the Picts is that shortly after the appearance of Miledh and the Scots in Ireland, the Cruithnigh came from the land of Thrace, being the children of 
Gleoin Mac Ercol (Gelonus, the son of Hercules) and being called Agathyrsi. They had passed through France where they built the city of Pictavis (Poitiers). They received a settlement in Ireland, till Eremon, son of Miledh, drove them out, giving them the wives of the men drowned with his brother Donn, when some of them settled in Ireland and the others sailed to dwell in the country beyond Ile, and conquered Alban from Cath to Forcu. The Irish legend 'of the descent of the Dalaraidhe' or Irish Picts says, 'Twice eighteen soldiers of the tribes of Thracia went to the fleet of the sons of Miledh to Germany, and they took them away with them and kept them as soldiers. They had no wives, and afterwards took wives of the race of Miledh ; and when they had cleared their swordland among the Britons, first Magh Fortrenn, and then Magh Girginn, the succession to the sovereignty was through females. There were thirty kings of the Cruithnigh over Erin and Alban, viz. of the Cruithnigh of Alban and of Erin. Seven kings of the Cruithnigh of Alban governed Ireland at Tara.' The legend of the Scottish Picts, contained in the Pictish Chronicle, says that the Scots, now corruptly called Hibernienses, were so called either as Scythians because they came from Scythia and derive their origin from it, or from Scota, daughter of Pharaoh, King of Egypt, who was, it is said, a queen of the Scots, and that the natives of Scythia were called from their fair hair Albani, and from these Albani both Scots and Picts derive their origin. The legend then tells that Cruithne, son of Cinge, was the father of the Picts inhabiting Britain, and had seven sons, one edition saying, 'And they divided the land into seven divisions, as Columcille says :-

\author{
Seven children of Cruithne \\ Divided Alban into seven divisions : \\ Cait, Ce, Cirig, a warlike clan, \\ Fib, Fidach, Fotla, Fortrenn,
}

and the name of each man is given to their territories.'

Five of these names are easily recognisable in the seven 
provinces of the Pictish kingdom north of the Forth. Cait is Caithness; Cirig Magh Girgin or the Mearns ; Fib, Fife; Fotla, Athfotla or Atholl;' and Fortrenn, the central district between the Forth and Tay. There follow a list of kings, among whom are two of the seven kings of Ireland, and the statements that thirty Brudes reigned over Alban and Erin for one hundred and fifty years, and in the Irish version that the account is taken from the books of the Cruithnigh. It seems clear that for many generations the Picts of Scotland and Ireland recognised each other as one people, and that there had been an ancient connection between them and the Milesian Scots. With this the Welsh name for the Picts, ' Gwyddil Ffichti,' Gaelic Picts, or Pictish Gael, coincides. The tradition that the Picts had at one time received their wives from the Scots, repeated by the British, Irish, and Saxon writers, undoubtedly points to a close similarity of language. In Layamon's Brut it is said:-

\footnotetext{
'Through the same women

Who there long dwelt

The folk began to speak

Ireland's speech,'
}

the underlying idea being that children always speak the language of their mothers, or 'the mother tongue.' Thus the retention by the legendary British settlers in Brittany, who were said to have taken wives of the country, of the Celtic speech is accounted for by the statement that having received the wives and daughters of the Armoricans in marriage they cut out their tongues lest the children should learn the mother tongue. The traditional intermarrying with the Scots is always associated with the peculiar Pictish law of succession-' so that it is in right of mothers they succeed to sovereignty and all other successions'; 'that they alone should take of the sovereignty and of the land from women rather than from men in Cruithintuath for ever'; 'that of women should be the royal succession among them for ever.' If there was any truth in the story of the Scottish stipulation, it bore effective fruit 
after many days when the Pictish throne passed to a Scottish line of kings.

The legend which brings the Picts from Thrace, and makes them originally Agathyrsi, receives some colour from the facts that the Agathyrsi, on the borders of the Black Sea, according to Pliny, painted the body, and according to Herodotus and Ammianus Marcellinus four hundred years later, had a community of wives, while the Agathyrsi and Thracians also practised the worship of Mercury whom Cæsar found venerated by the tribes of Gaul. Mercury worship and painting at least were not originally confined to the Picts, for the name of Briton apparently comes from the word 'Brith,' painted, while Giraldus Cambrensis records that 'Glaswir,' 'blue men,' was in his time the name for the Welsh clergy, probably a survival attached to the priestly caste from heathen times. It is probable that both Britons and Caledonians adopted the practice of painting from the earlier races among whom they found it observed.

The Celtic race consisted of two great branches, the Brythonic or Cymric, to which belong the Welsh or Cymry of Wales, the native population of Cornwall, and the Bretons of Brittany, the ancient Armorica, and the Gaelic or Erse to which belong the Irish, the Manx, and the Scottish Highlanders. The Welsh language differs from the Cornish, which only became extinct little more than a century ago, when Dolly Pentraeth died, and both from the Breton. Scottish Gaelic differs from Irish Gaelic, and both from Manx. In all these cases the difference is such as to constitute separate languages, and not dialects of the same. The older topography of Scotland, with the exception of a few words, that may be more archaic and Iberian in origin, is, in so far as it does not consist of more modern English or Teutonic names, generally Gaelic throughout the country to the north of the Forth and Clyde and in Galloway. In the south-eastern Lowlands Saxon names are frequent. In Strathclyde and Teviotdale British derivations are evident, and generally throughout the country to the south of the 
Forth and Clyde the nomenclature bears some relation to the various races that have met and mingled there. But north of the Forth substantially all the older names are Gaelic in form and sound, and except for the fact that in the Lowlands additional and more modern names of Teutonic sound and significance are numerous, there is no difference between the region of Argyll occupied by the Dalriad Scots, the whole mountainous region within the Highland line, where Gaelic was the language of daily life down to comparatively recent times, and the Lowland districts, where 'braid Scots' has been the tongue of the people for generations. The testimony of the Book of Deir, the names recorded of persons of some position as witnesses in earlier charters, and the nomenclature even later of the cultivating and servile classes, show that at a time when Buchan was Pictish, and when the rest of the eastern Lowlands were at least substantially Celtic, the names borne by the native population were Gaelic. Henry of Huntingdon, writing in the twelfth century, observes, 'The Picts now seem rooted out, and their language so completely destroyed, that already it seems a fable that mention of them is found in writings of men of old.' When we remember that the English tongue was introduced north of the Forth at least eight hundred years ago by Malcolm Canmore and his sons, and that it has not yet superseded the Gaelic in parts of the Highlands and the western isles, it is incredible that in the previous three hundred and fifty years the Scots of Argyllshire should have not only imposed an alien language on the whole population of the Highlands and north-eastern Lowlands, but successfully proscribed and replaced the designation of every natural feature and habitation of man over the whole of Alban. Still more incredible is it that this could have occurred without a hint in the Irish annals of any such change or of any complete difference of language, and that the legends recorded by Irish, Welsh, and Saxons should concur in accounting, by the tradition of Scottish wives, for the fact that the Picts spoke Gaelic. The Scottish 
missionaries found no linguistic difficulty in their work among the Picts. Columba himself used no interpreter at the court of King Brude at Inverness, nor apparently in his intercourse with 'Bede the Pict,' the Mormaer of Buchan at Deer, or with the aged chief whom he baptized in Glen Urquhart. He twice spoke by an interpreter, but it was always when preaching the Word of God. One occasion was when an aged chief named Artbrannan came to meet him in Skye from a more distant island; and the other when he preached to a peasant in the province of the Picts. The statement of Bede has been assumed to involve that Pictish was as distinct from Scottish, British, Saxon, and Latin as these were from each other, but it is only to the effect that the Word of Life was preached in the language of five nations. The Pictish Gaelic must have had its own peculiarities, and the dialect spoken by the humbler classes in different parts of the country probably varied largely from the cultivated Gaelic, intelligible alike to the Scottish clerics and the Pictish aristocracy. Indeed, it may have been mixed with the remains of a forgotten and unwritten Iberian speech, while there are reasons to believe that among the southern Picts it was largely affected by British influences. Agricola had found the great British tribe of the Damnonii in possession of the whole country from the Dumfriesshire hills to the Tay, and the Roman wall divided their territories into two, leaving outside the regions of Menteith and Strathearn, which are afterwards found as the Pictish province of Fortrenn. They were probably the Britons of Fortrenn of whom the Irish writers speak. One of the legends describes the Cruithne as clearing their swordland among the Britons in Magh Fortrenn, the plain of Fortrenn, and Magh Girginn, Girginn being Angus and Mearns, and Magh Girginn probably Strathmore and the Howe of the Mearns. From whom the Picts conquered Angus and Mearns, it is impossible to ascertain, but the one written relic of Pictish speech on the stone at St. Vigeans in Angus suggests a British element in their language, and 
they seem, when the scattered Roman garrisons beyond the wall were overwhelmed and withdrawn, to have overcome and incorporated the portion of the Damnonii north of the Forth. The extent to which Gaelic names are found to the south may be accounted for by the previous existence of a Pictish population conquered by the Britons from the south, or superseded by a British element during the Roman occupation, or by the settlements of Picts from the north after the Roman withdrawal.

The remains of the Pictish language are very scanty, and merely support the conclusion that it was a Gaelic speech modified by British influences, these being rather Cornish than Welsh in character, the Damnonii of the north being probably akin to the Dumnonii of Cornwall. The St. Vigeans Stone has been deciphered as reading 'Drosten ipe uoret Elt Forcus '- 'Drosten, the son of Voret, of the race of Fergus.' ' It is,' says Skene, ' a good specimen of the mixture of forms we find in this part of the Pictish territory. Drosten is not a Welsh form, but a Gaelic, Ipe Uoret Cornish, and Forcus unmistakably Irish.' It was in the immediate vicinity that in 731 Drust, one of the competitors for the Pictish throne, was defeated and slain by Angus MacFergus. In Cormac's Glossary occurs the word 'Cartit' - id est Delg (a pin) Berla Cruithnech (a Pictish word).' Dobur is given by Adamnan as the Pictish word for a river, the Gaelic being Dobhar, water. Reginald of Durham, who wrote in the later part of the twelfth century, records that certain clerics of Kirkcudbright were called in the language of the Picts ' Scollofthes,' which simply seems to be a Norman inflexion of the Irish 'Sgolog,' the Gaelic 'Scoloc,' and the Welsh 'Yscolheic.' Bede, in describing the northern wall, says it began two miles west of Abercorn at a place called in the language of the Picts Peanfahel, but in that of the Angles Penneltun, while it appears from Nennius that the British name was Penguaul, the head or end of the wall. It would therefore seem that the Picts had just modified the British name, VOL. VII. 
substituting the Gaelic F for the British Gu. Epithets are attached to some of the Pictish kings in the lists. Thus the Vipoig namet of the Pictish Chronicle is in the Latin lists Fiacha Albus, and namet appears to be a Pictish form of the Gaelic Neimheach, glittering or shining. Gartnait is called duiber or Duiperr, which is rendered in Latin Dives or the rich, and is the Irish word Saoibher, with the interchange-not unusual in Gaelic-of D for S. One of the Nectans is termed Morbet, which in Gaelic is Mor Breac, the great speckled or variegated one. The name of the Pictish Druid or Magus, Broichan, encountered by Columba, seems to be halfway between the Irish Brocan and the Welsh Brychan. The personal and place names in the earlier entries in the Book of Deir, at a time when the Pictish population of distant Buchan may be assumed to have been little affected, show no peculiarities distinguishing them from general Gaelic.

The names in the long list of the kings of the Picts given in the Pictish and other chronicles, exhibit a character of their own, but are mainly Gaelic forms. A considerable number are apparently of British derivation, and of Cornish rather than Welsh inflexion, and represent either a British word or the pronunciation of a Gaelic name by a people in which the British element was strong. The Cornish influence is indicated by the frequency of the syllable Ur and the letter $W$. There are also instances of the metamorphosis of a purely Teutonic name. The list does not necessarily indicate a direct line of monarchs ruling over the whole race. There was probably, as among the Irish Celts, an 'Ardrigh' or supreme king, with lesser kings, 'Righ,' ruling over the various provinces. There was probably at intervals at least a dual monarchy of the Northern and the Southern Picts, the old Caledonii and Meatæ, and one or two names can be identified as rulers of the Picts of Galloway. The Teutonic names may be accounted for by the fact that a considerable Pictish population was embraced in the Anglic kingdom of Northumbria 
when it reached to the Forth. The most common names are Drest or Drust, which occurs nine times, Talorcan six, Brude six times apart from the thirty Brudes, Gartnaidh four, a name also found among the Mormaers of Buchan and Mar, in the last of which it occurs as late as almost the War of Independence, and Nectan three times. Cinoid (Kenneth), Galan, Alpin, Ungus (Angus), and Urgust (Fergus), each occur twice. Of these Mr. Skene classifies Drust (Welsh Gorwst), Brude, Gartnaidh, Nectan and Cinoid as Gaelic, Talorcan as probably British, Galan either, Alpin as the Pictish form of the British Elffin, and Ungust and Wrgust as Cornish forms. The two latter may be the form and pronunciation given by the Southern Picts to the Gaelic Angus and Fergus. The only names referable to the Picts of Galloway are Drust and Cindaeladh. The earlier names are Gaelic, and in some instances are those of kings recorded as kings of Ireland as well as of the Scottish Picts ; the later ones of Gaelic character probably include the rulers of the Northern Picts ; those which are Cornish in resemblance probably belong to the region of the Southern Picts between Tay and Forth, and others including Welsh, Gaelic, and Teutonic names may belong to the Picts who seized the eastern districts between the walls, and were conquered by the Angles. The list begins in legendary times with Cruithne and his seven sons ; three kings follow, two of whom are the same as two of the Irish kings of the race of Ir. The next is a Welsh name, Guidid Gaidbrechach, termed in one of the Irish editions the Briton. Then come two Cornish forms, Gest and Wrgest, followed by the statement that thirty Brudes, of whom twenty-eight are given, reigned over Erin and Alban for a hundred and fifty years. Then come twenty-one names, including Dectotreic, who is evidently Theodric the son of Ida, called by the Welsh the Flamebearer, the last nine of which are Celtic, until with Brude MacMailchon, who received Columba at Inverness in 568, we reach authentic history. Meagre as the materials are, there can be little doubt that Skene 
is right in the conclusion that the Picts were mainly, and almost wholly in the north, a Gaelic people, that in central Scotland they were largely affected by a British element, and that their language was Gaelic, modified in the south by British influences. Their language was substantially the same as that spoken in the Highlands to-day, and of which lingering traces are found in Galloway in the eighteenth century. Reginald of Durham in 1164 speaks of Kirkcudbright as being in terra Pictorum, and calls the language there spoken sermo Pictorum. Buchanan in Queen Mary's time wrote that a great part of Galloway still used its ancient language. A Norman chronicler quoted in the Scala Chronica relates that the Picts obtained wives from Ireland ' on condition that their issue should speak Irish, which language remains to this day in the Highlands among those who are called Scots.' There can be little doubt that the same people north of the Forth were known in classic times as the Caledonii, later as the Picts, to the mediæval historians as 'the wild Scots,' and south of the Forth as the Novantæ, the Niduarian Picts, the 'Picts who are commonly called Galweienses' at the time of the battle of the Standard, and 'the wild Scots of Galloway.'

(To be continued.)

\section{HELGEBIORN THE HEATHEN}

\section{Alice Mrlligan}

I

I wILL tell you of Helgebiorn the Heathen and how he came to live the life of Peace. It was in Eilean Mór, of the Seven Hunters of holy Flannan, he found it, westward of Alba in the unbounded desolate sea. He was a man of blood before that, and now you shall hear how he forsook his sins under the guidance of Erc, disciple of Flannan, a servant of the one God. 